\title{
Antiproliferative Evaluation and Apoptosis Induction in MCF- 7 Cells by Ziziphus spina christi Leaf Extracts
}

\author{
Fatemeh Farmani ${ }^{1}$, Mahmoodreza Moein ${ }^{1,2}$, Amir Amanzadeh ${ }^{3}$, Hirsa \\ Mostafapour Kandelous ${ }^{4}$, Zahra Ehsanpour ${ }^{4}$, Mona Salimi ${ }^{4 *}$
}

\begin{abstract}
Background: Herbal medicine has becoming a potential source of treatment for different types of cancer including breast cancer. It has been shown that plants from the family Rhamnaceae possess anticancer activity. Objective: In this study, we determined the antiproliferative influence of Ziziphus spina christi- a species from this family- on the MCF-7 (human breast adenocarcinoma) cell line. Materials and Methods: The cytotoxicity of the total extract, ethanol, ethanol-aqueous (1:1) as well as aqueous fractions of Ziziphus spina christi leaves was evaluated through MTT assay against MCF-7 cell line. Cell cycle inhibition and apoptosis induction were assessed by flowcytometry cycle RNase/PI analysis and Annexin V-FLUOS, respectively. Apoptosis was also analyzed by immunoblotting assay. Results: Our results indicated that the ethanolic fraction had the lowest $\mathrm{IC}_{50}$ value $(0.02 \mathrm{mg} / \mathrm{ml})$, induced cell cycle arrest at the $\mathrm{G1} / \mathrm{S}$ phase as well as apoptosis after a $48 \mathrm{~h}$ of treatment. Conclusions: This is the first report on anticancer effect of Ziziphus spina christi ethanolic fraction on breast cancer cells, providing a scientific basis for its utility in traditional medicine. However, further in-depth studies are needed to confirm the precise mechanisms.
\end{abstract}

Keywords: Ziziphus spina christi - anticancer influence - MCF-7 - cell cycling - apoptosis

Asian Pac J Cancer Prev, 17 (1), 315-321

\section{Introduction}

Cancer is an increasing health issue whose worldwide incidence is about 6 million cases per year and characterized by unregulated cell proliferation (Srivastava et al., 2005; Thirumal et al., 2013; Quadri et al., 2014). Despite the advancing researches about cancer, there were not efficient strategies for cancer treatment. Therefore, scientists are still trying to find new compounds for treatment of this disease (Cragg \& Newman 2005). Plants have a long history of use in the treatment of cancer. Recently, a considerable percentage of anticancer drugs used in clinical are from natural resources (Demain \& Vaishnav 2011; Meng et al., 2012). Among them, taxol, camptothecin, vincristine, and vinblastine are the most important ones (Jain \& Jain 2011; Malik et al., 2011; Krifa et al., 2013; Thirumal et al., 2013). Natural products contain a structural diversity of chemical compounds possess therapeutic potential for treatment of cancer (Karon et al., 2011; Alshawsh et al., 2012).

Previous studies revealed the cytotoxic activity of Rhamnaceae family which consists of about 58 genera and approximately 900 species with worldwide distribution, mostly occurred in the subtropical and tropical regions (Rosas et al., 2007; Mishra et al., 2010; Silva et al., 2012). Ziziphus belongs to the family Rhamnaceae compromises more than 40 species and possesses different biological properties including antimicrobial, antioxidant, immunostimulant, antidiabetic, and anticancer effects (Richardson et al., 2000; Veeresh, 2010). Ziziphus spina christi L., commonly known as "Konar" or "Sedr" in Persian name, is an armed shrub or tree which widely cultivated in the southern parts of Iran. The plant fruit is edible sweet drupe and its leaves have been used as stomachic, emollient, antiulcer, disinfectant and antifungal in the Iranian traditional medicine (Ghannadi et al., 2003). Its leaves showed antibacterial, antidiarrhoeal, antiviral and antidiabetic activities (Ali-Shtayeh et al., 1998; Adzu et al., 2003; Michel et al., 2011). Studies revealed that Ziziphus spina christi possesses a diverse of biologically active chemical compounds including alkaloids like spinanine A, tanines, sterols like $\beta$ sitosterol, flavonoids such as rutin and quercetin derivatives, triterpenoids, sapogenins and saponins such as betulinic acid (Brantner \& Males 1999; Godini et al., 2009; Abalaka et al., 2010; Jinous \& Elaheh 2012). Based on the studies performed by Esteves-Souza et al. and Ren et al. (Esteves-Souza et al., 2002; Ren et al., 2003), these compounds exhibited anticancer activity in cancerous cell line (Abrahim et al., 2012; Karimi et al., 2012).

To the best of our knowledge, there are few

${ }^{1}$ Medicinal Plants Processing Research Center,School of Pharmacy, ${ }^{2}$ Department of Pharmacognosy, School of Pharmacy, Shiraz University of Medical Sciences, ${ }^{3}$ National Cell Bank of Iran, Pasteur Institute of Iran, ${ }^{4}$ Department of Physiology and Pharmacology, Pasteur Institute of Iran, Tehran, *For correspondence: salimimona@pasteur.ac.ir 
investigations about the anticancer activity of Ziziphus spina christi extracts, currently (Jafarian et al., 2014). Therefore, we decided to determine the antiproliferative activity of total extract as well as ethanol, ethanol-aqueous (1:1) and aqueous fractions obtained from Ziziphus spina christi leaves on breast cancer cells (MCF-7) and also investigate the apoptosis induction in this cell line.

\section{Materials and Methods}

\section{Reagents and cell line}

The human breast adenocarcinoma MCF-7 cell line (C135) was obtained from National Cell Bank of Pasteur Institute of Iran (NCBI) for studying anticancer properties of the extracts. Dulbecco's Modified Eagle's Medium (DMEM) and fetal bovine serum (FBS) were purchased from Gibco-BRL (Rockville, IN). Polyclonal anti-Bcl-2 (1:500), anti-Bax (1:500) and anti-GAPDH $(1: 1,000)$ antibodies were purchased from Abcam (Cambridge MA). Anti-rabbit IgG horseradish peroxidase (HRP) antibody $(1: 5,000)$ was obtained from Cell Signaling Technology (Beverly, MA). Annexin-V-FLUOS assay was performed with commercial kit purchased from Roche Applied Science (USA). ECL advance western blotting detection kit was prepared from General Electric Health Care Life Sciences (Buckinghamshire, UK). All other chemicals were in high purity and prepared from Merck (Darmstadt, Germany) and Sigma-Aldrich (St Louis, MO).

\section{Plant material and extracts preparation}

The leaves of Ziziphus spina christi were collected on December 2009 from Dashtestan-Bushehr and identified then authenticated by Mr. Sadeghi at the Fars Organization of Jahad-Agriculture, Iran. The leaves plant material was allowed to air dry and afterwards pulverized in a grinder. $1 \mathrm{~kg}$ of the pulverized material was extracted with $4000 \mathrm{ml}$ of ethanol $(80 \%, \mathrm{v} / \mathrm{v})$ at room temperature for $72 \mathrm{~h}$. The obtained total extract was then concentrated under reduced pressure, freeze-dried and stored at $-20^{\circ} \mathrm{C}$ until use.

\section{Column chromatography of leaf extract}

Column chromatography was performed on the total extract using amberlite resin as the stationary phase and ethanol, ethanol-aqueous and aqueous as the mobile phases. Successive fractions were collected and dried under vacuum using a freeze-dryer.

\section{In vitro assay for cytotoxicity activity}

MCF-7 cells were routinely cultured in DMEM medium supplemented with $10 \% \mathrm{FBS}, 100 \mathrm{U} / \mathrm{ml}$ penicillin and $100 \mu \mathrm{g} / \mathrm{ml}$ streptomycin under the conditions of $5 \%$ $\mathrm{CO}_{2}$ at $37^{\circ} \mathrm{C}$. Total extract as well as fractions were tested for their cytotoxic effects toward cancer cells using the MTT assay. Briefly, MCF-7 cells $\left(7 \times 10^{3}\right)$ cells/well were cultured in 96-well plates. Then, cells were treated with various concentrations of each extract $(0.5-0.001 \mathrm{mg} / \mathrm{ml})$ and incubated for 24, 48 and $72 \mathrm{~h}$. Afterwards, $20 \mu \mathrm{l}$ of 3- (4, 5-dimethylthiazol-2-yl)-2, 5-diphenyltetrazolium bromide (MTT, $5 \mathrm{mg} / \mathrm{ml}$ in PBS) was added to each well and the cells were incubated for another $4 \mathrm{~h}$ at 37 ${ }^{\circ} \mathrm{C}$. Following aspiration of the supernatants, $200 \mu \mathrm{l}$ of dimethyl sulfoxide (DMSO) was added to each well. After shaking of the plates, the absorbance values were read by the Microplate Reader (Star Fax-2100, ST. Louis, USA) at $545 \mathrm{~nm}$. Solvent control (DMSO) was included to check that the DMSO had no effect at the concentration used. The cytotoxicity of the extracts was measured from the spectrophotometric data by means of this equation: \% cell cytotoxicity $=[1-$ Abs extract/Abs control $] \times 100$.The $\mathrm{IC}_{50}$ value was measured by plotting the percentage of cytotoxicity versus concentration on a logarithmic graph.

\section{Flowcytometric analysis}

Cell cycle phase distribution was determined by analytical DNA flowcytometry. For determination of cell cycle phases, peak area of FL3-A was recorded on a linear scale. Percentage of cells in sub-G1, G1, S and G2/M phases was determined by PARTEC flowcytometry (Partec GmbH, Munster, Germany) using Flowjo Software. In brief, MCF-7 cells in the exponential phase of growth were seeded in 6-well plates and allowed to adhere for $24 \mathrm{~h}$. Then, cells were treated without and with the ethanolic extract at $1 / 2 \mathrm{IC}_{50}$ concentration $(0.04 \mathrm{mg} / \mathrm{ml})$ and further incubated for $48 \mathrm{~h}$. After trypsinization and centrifugation, cells were fixed in $70 \%$ ethanol, washed in PBS, subjected to RNase digestion, followed by staining of clean nuclear material (nuclei) with PI $(1 \mathrm{mg} / \mathrm{ml})$. Cells treated with $0.3 \%$ DMSO, were used as solvent control. Triplicate samples were prepared for each treatment, and each experiment was repeated at least three times. In all flowcytometric determinations, suitable gating was employed to exclude cell debris and cell clumps from the analysis.

\section{Annexin-V staining assay}

The plasma membrane changes characteristics of apoptosis were analyzed by double staining with AnnexinV-FLUOS and Propidium Iodide (PI) according to the manufacturer's instructions. To perform this assay, untreated and treated-cells $1 / 2 \mathrm{IC}_{50}$ concentration of the ethanolic fraction, were harvested and resuspended in 100 $\mu l$ of the annexin-V-FLUOS labeling solution containing $2 \mu \mathrm{l}$ annexin-V-FLUOS labeling agent, $2 \mu \mathrm{l}$ Propidium Iodide (PI) solution and $1 \mathrm{ml}$ incubation buffer to achieve a concentration of $10^{6}$ cells $/ \mathrm{ml}$ and incubated at $37^{\circ} \mathrm{C}$. Each tube was diluted with buffer before the cells were analyzed by flowcytometry. In the dual parameter fluorescent dot plots, three populations of cells were observed: Viable cells: annexin-V negative and PI negative; Apoptotic cells: annexin-V positive and PI negative; Late apoptotic/ necrotic cells: annexin-V positive and PI positive or and annexin- $\mathrm{V}$ negative and PI positive.

\section{Western blot analysis}

MCF-7 cells were treated with the ethanolic fraction $1 / 2 \mathrm{IC}_{50}$ concentration for $48 \mathrm{~h}$. Proteins were collected and lyzed in lysis buffer [Tris $62.5 \mathrm{mM}, \mathrm{pH} 6.8$; dithiothreitol, $50 \mathrm{mM}$; sodium dodecyl sulphate, 10\%; glycerol, $10 \%$; bromophenol blue, $0.25 \%(\mathrm{w} / \mathrm{v})$ ] in the presence of protease inhibitor. The proteins were separated by $12 \%$ sodium dodecyl sulfate polyacrylamide gel electrophoresis (SDS-PAGE) and transferred to polyvinylidene 
a)
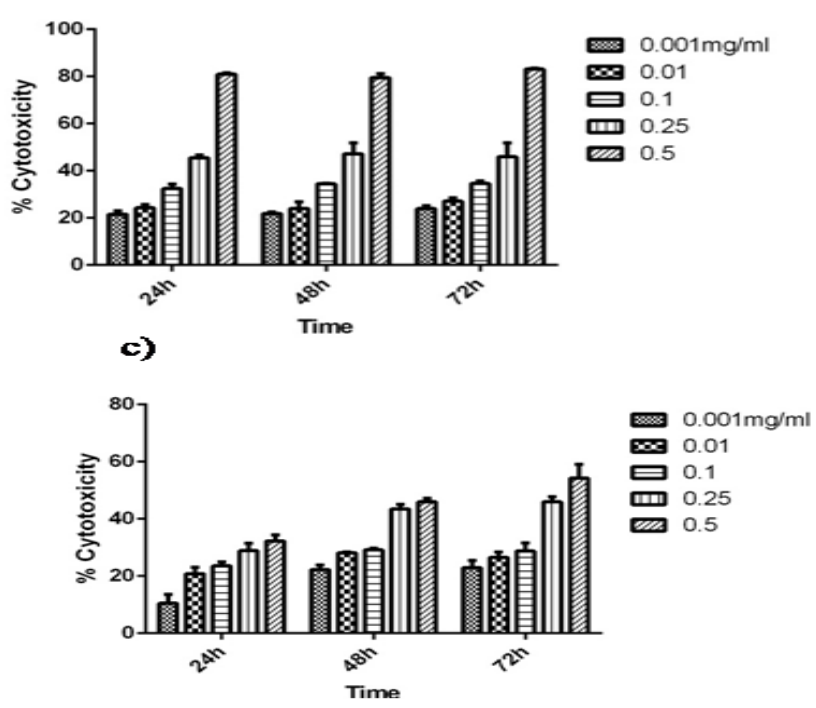

b)

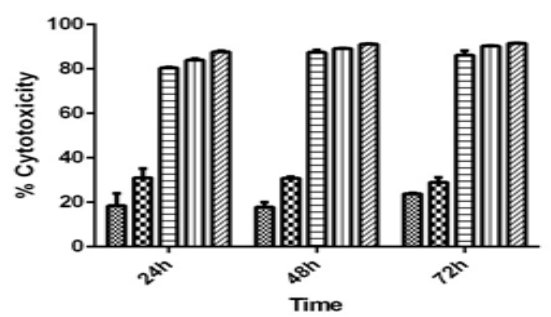

$0.001 \mathrm{mg} / \mathrm{ml}$ 0.01 曰 0.1 뚀 0.25 0.5

d)

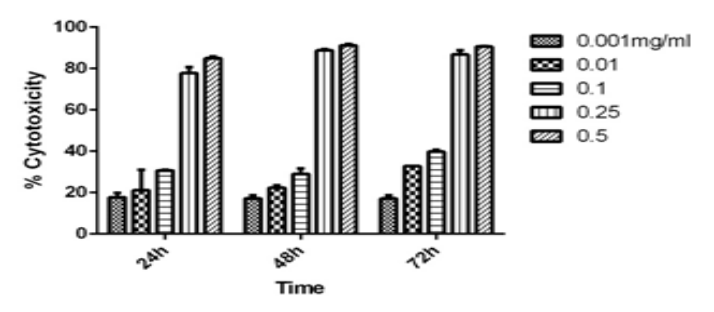

Figure 1. Effect of a) Total Extract, b) Ethanol, c) Ethanol-aqueous and d) Aqueous Fractions on MCF-7 Cells after 24, 48 and 72h Treatment. Cells were treated with different concentrations of extracts $(0.001-0.5 \mathrm{mg} / \mathrm{ml})$.Values are presented as mean $\pm \mathrm{SE}$ of three independent experiments, performed in triplicate

Table 1. IC ${ }_{50}$ Values (mg of extract/ml) for Antiproliferative Activity of Ziziphus spina christi Different Extracts Towards MCF-7 Cells

\begin{tabular}{lccccc}
\hline Cells & Time & Total extract & Ethanol fraction & Ethanol/Aqueous fraction & Aqueous fraction \\
\hline \multirow{2}{*}{ MCF-7 } & $24 \mathrm{~h}$ & $0.23(0.16-0.3)$ & $0.02(0.01-0.03)$ & $>0.5$ & $0.14(0.07-0.16)$ \\
& $48 \mathrm{~h}$ & $0.23(0.17-0.3)$ & $0.02(0.01-0.03)$ & $>0.5$ & $0.14(0.11-0.17)$ \\
& $72 \mathrm{~h}$ & $0.24(0.16-0.3)$ & $0.02(0.01-0.03)$ & $0.3(0.2-0.4)$ & $0.12(0.1-0.14)$ \\
\hline
\end{tabular}

MCF-7: human breast adenocarcinoma. Data are expressed as mean of three separate experiments run in triplicate and $95 \%$ confidence intervals

fluoride membranes (GE Health Care Life Sciences, Buckinghamshire, UK) using wet blotting apparatus (Bio-Rad, Hercules, CA, USA). The membranes were blocked in tris-buffered saline containing (TBS) $0.05 \%$ Tween 20 (TBST) and $1 \%$ casein (w/v) for $2 \mathrm{~h}$, followed by incubation with the indicated primary antibody overnight at $4{ }^{\circ} \mathrm{C}$. The membranes were then washed three times for 10 min with TBST, followed by incubation with the secondary antibody. After washing $3 \times 10 \mathrm{~min}$, protein expression was detected by chemiluminescence emission using ECL and then the blots were exposed to x-ray films. GAPDH (glyceraldehyde phosphate dehydrogenase) was used as the endogenous control and the control cells were cultured in the complete medium without extracts (control cells were only treated with DMSO using the highest amount into the experiments).

\section{Statistical analysis}

Triplicates of three independent experiments were carried out and data are expressed as the mean $\pm \mathrm{SE}$. Corresponding $95 \%$ confidence interval $(95 \% \mathrm{CI})$ was computed to assess the $\mathrm{IC}_{50}$ values. Differences between the groups were evaluated by using one-way analysis of variance (ANOVA) followed by post hoc Tukey multiple comparison test with the aid of Graph Pad Prism 5 software. t-test was used to compare two different groups. $\mathrm{p}<0.05$ was taken as being statistically significant.
Table 2. Effect of Ethanol Fraction on Cell Cycle Progression with Respect to Solvent Control after 48 h Treatment ${ }^{\mathrm{a}}$

\begin{tabular}{|c|c|c|c|c|}
\hline \multirow[b]{2}{*}{ Treatment } & \multicolumn{4}{|c|}{$\mathrm{MCF}-7$} \\
\hline & $\begin{array}{c}\text { Sub-G1 } \\
(\text { mean } \pm \text { SE) }\end{array}$ & $\begin{array}{c}\mathrm{Go} / \mathrm{G} 1 \\
(\mathrm{mean} \pm \mathrm{SE})\end{array}$ & $\begin{array}{c}\mathrm{S} \\
(\text { mean } \pm \mathrm{SE})\end{array}$ & $\begin{array}{c}\mathrm{G} 2 / \mathrm{M} \\
(\mathrm{mean} \pm \mathrm{SE})\end{array}$ \\
\hline Solvent -Control & $20.36 \pm 2.09$ & $20.67 \pm 1.5$ & $30.98 \pm 1.1$ & $14.01 \pm 1.2$ \\
\hline $0.04 \mathrm{mg} / \mathrm{ml}$ & $31.35 \pm 2.2 * *$ & $30.90 \pm 2.2 *$ & $24.3 \pm 0.3 * * *$ & $9.0 \pm 0.1 * * *$ \\
\hline
\end{tabular}

${ }^{\mathrm{a}} \mathrm{At}$ the indicated cell, distribution of the cells in sub-G1, Go/G1, S and $\mathrm{G} 2 / \mathrm{M}$ phase was analyzed by flowcytometry as described in materials and methods. Results are expressed as total cells. Data represent means of triplicate experiment. $* \mathrm{P}<0.05, * * \mathrm{P}<0.01, * * * \mathrm{P}<0.001$ relative to control

\section{Results}

\section{Antiproliferative activity of extracts}

After 24, 48 and 72 hours of incubation, the results indicated that Ziziphus spina christi total extract and fractions decreased cell viability in a dose-dependent manner (Figure 1). The related $\mathrm{IC}_{50}$ values are shown in Table 1. Inhibition of the proliferation of MCF-7 cells by the ethanol fraction, reached a maximum of $80.95 \%, 91.13 \%$ and $91.50 \%$ at a concentration of 0.5 $\mathrm{mg} / \mathrm{ml}$ after 24, 48 and 72 hours of incubation (Figure 1). Interestingly, ethanolic fraction indicated the lowest $\mathrm{IC}_{50}$ value compared to other fractions at three different times (Table 1). 
Ethanol fraction induces cell cycle arrest in MCF-7 cells

Since cell proliferation is due to the progression of the cells via the different phases of cell cycle, we next examined the effects of the ethanolic fraction as the most potent extract to induce cell cytotoxicity on the cell cycle distribution by flowcytometry. Cultured MCF-7 cells were incubated with $0.04 \mathrm{mg} / \mathrm{ml}\left(2 \times \mathrm{IC}_{50}\right)$ of the ethanol fraction for $48 \mathrm{~h}$, stained with PI and analyzed by flowcytometry in order to determine the total population distribution in the different phases $(\mathrm{G} 0 / \mathrm{G} 1, \mathrm{~S}$, and G2/M). Control cells treated only with DMSO using the highest amount into the experiments. MCF-7 cells treated with $0.04 \mathrm{mg} / \mathrm{ml}$ of ethanol fraction were observed to have a statistically significant increase of cell population in G1 phase from $20.67 \%$ for control to $30.90 \%$ after treatment, while cell population in $\mathrm{S}$ phase significantly decreased in MCF7 treated cells (Table 2). It appears therefore that the ethanolic fraction is able to inhibit the proliferation of MCF-7cells by promoting cell cycle arrest at the G1/S phase. Additionally, following $48 \mathrm{~h}$ of treatment, the

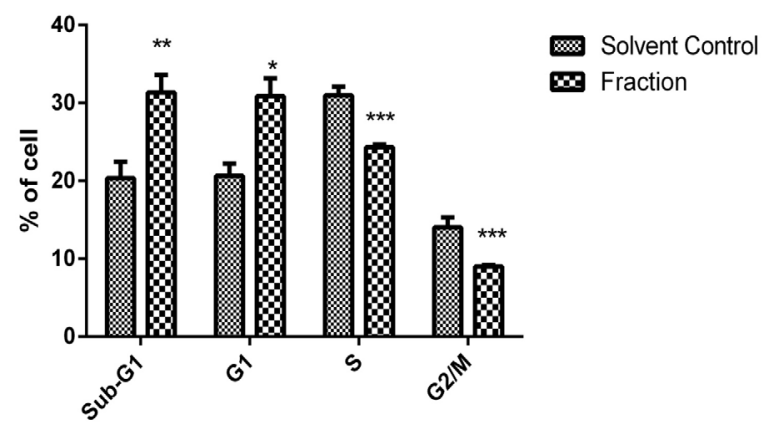

Figure 2. Distribution of the Cell Cycle of MCF-7 Cells was Assessed by Flowcytometry after Staining with Propidium Iodide (PI). The data presented are the mean \pm $\mathrm{SE}$ of three independent experiments. $* \mathrm{P}<0.05, * * * \mathrm{P}<0.01$ as compared to solvent control after $48 \mathrm{~h}$ treatment with ethanol fraction
sub-G1 population significantly increased from $20.36 \%$ to $31.35 \%$ (Figure 2). These observations imply that the growth inhibition is probably due to a combination of apoptosis and cell cycle disarrangement.

\section{Ethanol fraction induces apoptosis in MCF-7 cells}

To confirm that the ethanolic fraction induces MCF-7 cell apoptosis, cells were stained with annexin-V and PI, and subsequently analyzed by flowcytometry. This assay is based on the externalization of phosphatidylserine from the inner leaflet of the plasma membrane to the cell surface in the early apoptotic cells. MCF-7 cells were treated with the ethanolic fraction at $0.01 \mathrm{mg} / \mathrm{ml}\left(1 / 2 \mathrm{IC}_{50}\right)$ for $48 \mathrm{~h}$. In control and DMSO-treated cells, 4.8 and $6.2 \%$ of cells were annexin $\mathrm{V}+/ \mathrm{PI}-$ and 2.1 and $3.7 \%$ of cells were annexin $\mathrm{V}+/ \mathrm{PI}+$. After treatment with ethanol fraction at $0.01 \mathrm{mg} / \mathrm{ml}$ for $48 \mathrm{~h}$, the corresponding quantities were 3.2 and $8.4 \%$ respectively (Table 3 ). Meanwhile, the necrotic population (annexin V - /PI +) was increased by $6.0 \%$ after ethanolic fraction treatment.

Western blotting analysis on apoptosis signaling pathway

Western blotting was used in order to analyze the proteins related to apoptosis induced by the ethanolic fraction in MCF-7 cells. Two major pathways involved in the process have been thoroughly investigated; deathreceptor and mitochondrial pathways. Mitochondrial

Table 3. Percentage of Breast Adenocarcinoma Cells in Each State after Treatment with Ethanol Fraction at $0.01 \mathrm{mg} / \mathrm{ml}$ for $48 \mathrm{~h}$ of Incubation

\begin{tabular}{lcccc}
\hline Compound & \multicolumn{2}{c}{ Vital } & Early & \multicolumn{2}{c}{ Late } & Necrosis \\
& cells (\%) & apoptosis (\%) & apoptosis $(\%)$ & $(\%)$ \\
An-/PI- & An+/PI- & An+/PI+ & An-/PI+ \\
\hline Ethanol Fraction & $76.3 \pm 1.8^{* * *}$ & $3.2 \pm 0.4^{*}$ & $8.4 \pm 1.1^{*}$ & $12.9 \pm 3.4^{* * *}$ \\
Control & $86.9 \pm 1.4$ & $4.8 \pm 0.6$ & $2.1 \pm 0.07$ & $5.9 \pm 1.2$ \\
Solvent-Control & $80.1 \pm 0.6$ & $6.2 \pm 1.2$ & $3.7 \pm 0.3$ & $6.8 \pm 0.9$ \\
\hline
\end{tabular}

The data presented are the mean \pm SE of three independent experiments. $* \mathrm{P}<0.05, * * * \mathrm{P}<0.001$ as compared to Solvent-Control a)

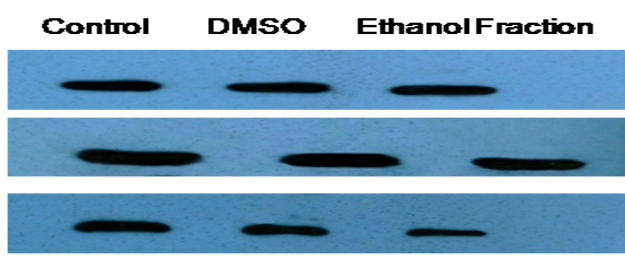

c)

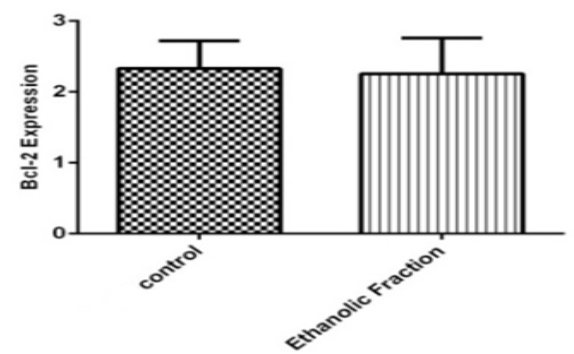

$\mathbf{B a x}$

Bcl,

GAPDH

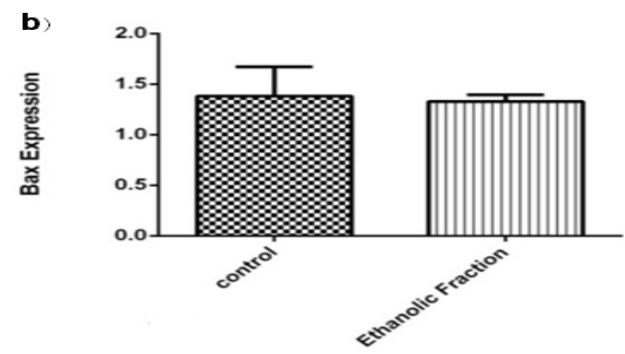

d)

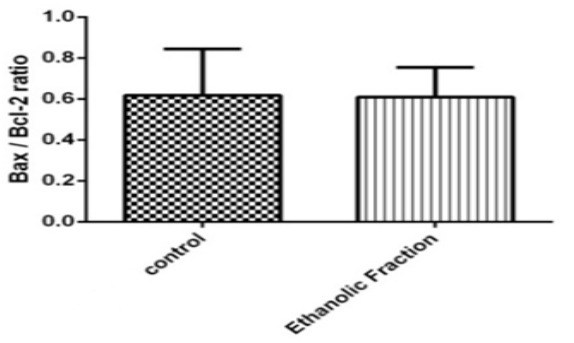

Figure 3. Effect of the Ethanolic Fraction at 1/2 IC ${ }_{50}$ concentration on the Levels of Bax and Bcl-2 Protein Expression in MCF-7 Cancer Cell Line. a)Bax and Bcl-2 protein levels were assayed by western blotting. The expression of b)Bax, c)Bcl-2 and d)Bax/Bcl-2 ratio were measured after $48 \mathrm{~h}$ of treatment. Differences between the Bax and Bcl-2 in treated and their respective control cells were determined by Unpaired t Test 
pathway considered as an important mediator of apoptosis (Chandra et al., 2002; Teijido and Dejean 2010). Bcl-2 family members are responsible for the regulation of apoptosis in mitochondrial pathway which contain the anti-apoptotic Bcl-2 and pro-apoptotic Bax proteins (Pratt et al., 2007). Our results showed that the MCF-7 cell line was highly expressed in Bcl-2. Following treatment with the ethanolic fraction, no significant change was observed in the Bcl-2 and Bax expressions (Figure 3). The Bax- toBcl-2 ratio suggests that induction of apoptosis by the ethanolic fraction is not through the intrinsic pathway.

\section{Discussion}

Cancer is the second leading cause of death following heart diseases (Beeran et al., 2015). Although cancer therapies have been developed significantly in the last few years, cancer has been still considered as a complex disease (Cheng et al.,2012). Medicinal plants have played a decisive role in the area of cancer chemotherapy due to minimal side effects and anti-multidrug resistance (Cheng et al., 2012; Cragg \& Newman 2005). In this respect, 60\% of the anticancer drugs currently used have been isolated from natural products (Brantner \& Males 1999).

Ziziphus spina christi has been commonly used in TCM for treating various diseases such as digestive disorders, weakness, liver complaints, obesity, urinary troubles, diabetes, skin infections, loss of appetite, fever, pharyngitis, bronchitis, anemia, diarrhea, insomnia, and cancer (Brown 1995; Him-Che 1985; Plastina et al., 2012). Recently, much attention has been focused on verifying the effectiveness of Ziziphus against cancer. In this regard, it has been shown that Ziziphus extracts, alone or in combination with other botanical formulations, reveal anticancer activities on several tumor cell lines (Chan et al., 2005; Huang et al., 2007; Huang et al., 2009; Lee et al., 2003; Saif et al., 2010; Vahedi et al., 2008). To our knowledge, little is known about the antiproliferative effect of different fractions obtained from Ziziphus spina christi.

The current study investigated the antiproliferative properties of total extract as well as ethanol, ethanolaqueous and aqueous fractions in human breast adinocarcinoma cells (MCF-7). In consistence with the literature (Jafarian et al., 2014), cytotoxicity studies revealed that the total extract possessed a concentrationdependent increase in the cell cytotoxicity in MCF-7 cells with an $\mathrm{IC}_{50}$ of $0.2 \mathrm{mg} / \mathrm{ml}$. Therefore, fractionation strategy was used to identify the most active fractions against breast cancer cell line. Among all the fractions tested for cytotoxic effects in MCF-7 cells, ethanolic fraction was found to be highly active with an $\mathrm{IC}_{50}$ of $0.02 \mathrm{mg} / \mathrm{ml}$. Interestingly, no time-dependency was observed in cytotoxic activity of ethanolic fraction on this cell line. It has been previously demonstrated that induction of apoptosis is one of the mechanisms for the anticancer activities of Ziziphus extracts in different cell lines (Huang et al., 2007; Vahedi et al., 2008). In agreement with the reported results, our annexin- $\mathrm{V}$ assay for apoptosis exhibited that the ethanolic fraction induced apoptosis in MCF-7 cells after $48 \mathrm{~h}$ of incubation at1/2
$\mathrm{IC}_{50}$ concentration (Table 3 ).

It has long been reported that outcome of cellular viability/apoptosis is determined by the expression of proand anti-apoptotic proteins as well as the ratio between them (Gao \& Dou 2000; Tasyriq et al., 2012; Kumar et al., 2013). In this respect, over-expression of Bcl-2 protein inhibits apoptosis whereby up-regulation of Bax protein induces apoptosis in the cancer cells ( $\mathrm{Ng}$ et al., 2011; Mohan et al., 2012; Wu et al., 2012). In the present study, the ethanolic fraction revealed no significant change on the Bax or Bcl-2 expression at the protein level suggesting an independent mitochondrial apoptotic pathway induced by the ethanolic fraction.

Alteration of DNA content induced by disturbance of cell cycle progression plays a pivotal role in the proliferation of cancer cells. Many anticancer drugs such as camptothecin, doxorubicin, cisplatin, 5-fluorouracil act through cell cycle arrest (Pieme et al., 2014). Here, put forwards this question whether G1/S phase arrest induced by Ziziphus spina christi ethanolic fraction is the prominent pathway for cytotoxic effects in MCF-7 cells or not. Our results revealed an accumulation of G1 phase when the MCF-7 cells were treated with the ethanolic fraction of Ziziphus spina christi at $2 \times \mathrm{IC}_{50}$ for $48 \mathrm{~h}$. The proportion of cells with DNA content in G0 phase also showed a significant increase. These results propose that the apoptosis induced by the Ziziphus spina christi ethanolic fraction may be through the perturbation of MCF-7 cell cycle progression.

In conclusion, ethanol fraction of Ziziphus spina christi demonstrates antiproliferative properties on MCF7 cells by inducing apoptosis and G1/S phase cell arrest. However, our data exhibit that apoptosis induction is through a mitochondrial-independent pathway suggesting possible anticancer bioactive compounds which require isolation and further characterization. Indeed, further-in depth mechanism involved in apoptosis yet needs to be investigated as well as the identification of the active molecules present in the different parts of the plant.

\section{Acknowledgements}

This work was supported by Pasteur Institute of Iran and Medicinal plants processing Research Center of Shiraz University of Medical sciences (Grant number 8952).

\section{References}

Abalaka ME, Daniyan SY, Mann A (2010). Evaluation of the antimicrobial activities of two Ziziphus species (Ziziphus mauritiana L. and Ziziphus spinachristi L.) on some microbial pathogens. Afr J pharm pharmacol, 4, 135-9.

Abrahim NN, Kanthimathi M, Abdul-Aziz A (2012). Piper betle shows antioxidant activities, inhibits MCF-7 cell proliferation and increases activities of catalase and superoxide dismutase. BMC Complement Alternat Med, 12, 220 .

Adzu B, Amos S, Amizan M, Gamaniel K (2003). Evaluation of the antidiarrhoeal effects of Zizyphus spina-christi stem bark in rats. $J$ Acta Trop, 87, 245-50.

Ali-Shtayeh M, Yaghmour RM-R, Faidi Y, et al (1998). Antimicrobial activity of 20 plants used in folkloric medicine 
in the Palestinian area. J Ethnopharm, 60, 265-71.

Alshawsh MA, Abdulla MA, Ismail S, et al (2012). Free radical scavenging, antimicrobial and immunomodulatory activities of orthosiphon stamineus. J Art Mol, 17, 5385-95.

Asgarpanah J, Haghighat E (2012). Phytochemistry and pharmacologic properties of Ziziphus spina christi (L.) Willd. Afr J Pharm \& Pharmacol, 6, 2332-9.

Beeran AA, Maliyakkal N, Rao CM, Udupa N (2015). The enriched fraction of Elephantopus scaber Triggers apoptosis and inhibits multi-drug resistance transporters in human epithelial cancer cells. Pharmacogn Mag, 11, 257.

Brantner AH, Males Z (1999). Quality assessment of Paliurus spina-christi extracts. J Ethnopharmacol, 66, 175-9.

Brown D (1995). Encyclopaedia of herbs and their uses. london: dorling kindersley.

Chan ASL, Yip EC-H, Yung LY, et al (2005). Immuno-regulatory effects of CKBM on the activities of mitogen-activated protein kinases and the release of cytokines in THP-1 monocytic cells. Bio Pharm Bull, 28, 1645-50.

Chandra D, Liu J-W, Tang DG (2002). Early mitochondrial activation and cytochrome $\mathrm{c}$ up-regulation during apoptosis. J Biol Chem, 277, 50842-54.

Cheng X, Xiao Y, Wang X, et al (2012). Anti-tumor and pro-apoptotic activity of ethanolic extract and its various fractions from Polytrichum commune L. ex Hedw in L1210 cells. J Ethno Pharmacol, 143, 49-56.

Cragg GM, Newman DJ (2005). Plants as a source of anti-cancer agents. J Ethnopharmacol, 100, 72-79.

Demain AL, Vaishnav P (2011). Natural products for cancer chemotherapy. Microb biotech, 6, 687-99.

Esteves-Souza A, Silva TM, Alves CCF, et al (2002). Cytotoxic activities against Ehrlich carcinoma and human K562 leukaemia of alkaloids and flavonoid from two Solanum species. J Braz Chem Soc, 13, 838-42.

Gao G, Dou QP (2000). G1 phase-dependent expression of Bcl-2 mRNA and protein correlates with chemoresistance of human cancer cells. Mol Pharmacol, 58, 1001-10.

Ghannadi A, Tavakoli N, Mehri-Ardestani M (2003). Volatile constituents of the leaves of Ziziphus spina-christi (L.) Willd. from Bushehr, Iran. J Essen Oil Res, 15, 191-2.

Godini A, Kazem M, Naseri G, Badavi M (2009). The effect of Zizyphus Spina-Christi leaf extract on the isolated rat aorta. J Pak Med Assoc, 59, 537-9.

Him-Che Y (1985). Handbook of Chinese herbs and formulas. Losangeles, CA: Institute of Chinese Medicine.

Huang X, Kojima-Yuasa A, Norikura T, et al (2007). Mechanism of the anti-cancer activity of Zizyphus jujuba in HepG2 cells. Am J Chin Med, 35, 517-32.

Huang X, Kojima-Yuasa A, Xu S, et al (2009). Combination of Zizyphus jujuba and green tea extracts exerts excellent cytotoxic activity in HepG2 cells via reducing the expression of APRIL. Am J Chin Med, 37, 169-79.

Jafarian A, Zolfaghari B, Shirani K (2014). Cytotoxicity of different extracts of arial parts of Ziziphus spina-christi on HeLa and MDA-MB-468 tumor cells. Adv Biomed Res, 3, 38.

Jain R, Jain SK (2011). Screening of cytotoxic activity of some medicinal plants used traditionally to treat cancer in Chhattisgarh state, India. Asian Pac J Trop Biomed, 1, 147-50.

Karimi E, Oskoueian E, Hendra R, et al (2012). Phenolic compounds characterization and biological activities of citrus aurantium bloom. Molecules, 17, 1203-18.

Karon B, Ibrahim M, Mahmood A, et al (2011). Preliminary antimicrobial, cytotoxic and chemical investigations of averrhoa bilimbi linn. and Zizyphus mauritiana Lam. Bangladesh Pharm J, 14, 127-31.

Krifa M, Alhosin M, Muller CD, et al (2013). Limoniastrum guyonianum aqueous gall extract induces apoptosis in human cervical cancer cells involving p16 INK4A re-expression related to UHRF1 and DNMT1 down-regulation.J Exp Clin Cancer Res, 32, 30-40.

Kumar H, Kim I-S, More SV, et al (2013). Gastrodin protects apoptotic dopaminergic neurons in a toxin-induced Parkinson's disease model. Evid Based Complement Alternat Med, 2013, 514095.

Lee SM, Min BS, Lee C-G, et al (2003). Cytotoxic triterpenoids from the fruits of Zizyphus jujuba. Planta medica, 69, 1051-4.

Malik S, Cusidó RM, Mirjalili MH, et al (2011). Production of the anticancer drug taxol inTaxus baccata suspension cultures: A review. Proc Biochem, 46, 23-34.

Meng FM, Yang JB, Yang CH, et al (2012). Vitexicarpin induces apoptosis in human prostate carcinoma PC-3 cells through G2/M phase arrest. Asian Pac J Cancer Prev, 13, 6369-74.

Michel CG, Nesseem DI, Ismail MF (2011). Anti-diabetic activity and stability study of the formulated leaf extract of Zizyphus spina-christi (L.) Willd with the influence of seasonal variation. J Ethnopharmacol, 133, 53-62.

Mishra T, Khullar M, Bhatia A (2010). Anticancer potential of aqueous ethanol seed extract of Ziziphus mauritiana against cancer cell lines and Ehrlich ascites carcinoma.J Evid Based Complement Alternt Med, 8, 101-111.

Mohan S, Abdelwahab SI, Kamalidehghan B, et al (2012). Involvement of $\mathrm{NF}-x \mathrm{~B}$ and $\mathrm{Bcl} 2 / \mathrm{Bax}$ signaling pathways in the apoptosis of MCF7 cells induced by a xanthone compound Pyranocycloartobiloxanthone A. Phytomedicine, 19, 1007-15.

$\mathrm{Ng}$ WK, Yazan LS, Ismail M (2011). Thymoquinone from Nigella sativa was more potent than cisplatin in eliminating of SiHa cells via apoptosis with down-regulation of Bcl-2 protein. Toxicol in vitro, 25, 1392-8.

Pieme CA, Santosh G, Tekwu E, et al (2014). Fruits and barks extracts of Zanthozyllum heitzii a spice from Cameroon induce mitochondrial dependent apoptosis and Go/G1 phase arrest in human leukemia HL-60 cells. Biol Res, 47, 1-13.

Plastina P, Bonofiglio D, Vizza D, et al (2012). Identification of bioactive constituents of Ziziphus jujube fruit extracts exerting antiproliferative and apoptotic effects in human breast cancer cells. J Ethnopharmacol, 140, 325-32.

Pratt MC, White D, Kushwaha N, et al (2007). Cytoplasmic mutant $\mathrm{p} 53$ increases Bcl-2 expression in estrogen receptorpositive breast cancer cells. Apoptosis, 12, 657-69.

Quadri MFA, Saleh MS, Alsanosy R, et al (2014). Effectiveness of an intervention program on knowledge of oral cancer among the youth of Jazan, Saudi Arabia. Asian Pac J Cancer Prev, 15, 1913-8.

Ren W, Qiao Z, Wang H, et al (2003). Flavonoids: promising anticancer agents. Med Res Rev, 23, 519-34.

Richardson JE, Fay MF, Cronk QC, et al (2000). A phylogenetic analysis of Rhamnaceae using rbcL and trnL-F plastid DNA sequences. Am J Bot, 87, 1309-24.

Rosas L, Cordeiro MS, Campos FR, et al (2007). In vitro evaluation of the cytotoxic and trypanocidal activities of Ampelozizyphus amazonicus (Rhamnaceae). Braz J Med Biol Res, 40, 663-70.

Saif MW, Lansigan F, Ruta S, et al (2010). Phase I study of the botanical formulation PHY906 with capecitabine in advanced pancreatic and other gastrointestinal malignancies. Phytomedicine, 17, 161-9.

Silva ERd, Diedrich D, Bolzan RC, Giacomelli SR (2012). Toxicological and pharmacological evaluation of Discaria americana Gillies \& Hook (Rhamnaceae) in mice.J Pharm Sci, 48, 273-80.

Srivastava V, Negi AS, Kumar J, et al (2005). Plant-based 
anticancer molecules: a chemical and biological profile of some important leads. Bioorg Med Chem, 13, 5892-908.

Tasyriq M, Najmuldeen IA, In LL, et al (2012). $7 \alpha$-Hydroxy$\beta$ Sitosterol from Chisocheton tomentosus induces apoptosis via dysregulation of cellular Bax/Bcl-2 ratio and cell cycle arrest by downregulating ERK1/2 activation. Evid Based Complement Alternat Med, 765316.

Teijido O, Dejean L (2010). Upregulation of Bcl2 inhibits apoptosis-driven BAX insertion but favors BAX relocalization in mitochondria. FEBS letters, 584, 3305-10.

Thirumal M, Kishore G, Surya S (2013). Antiproliferative activity of various parts of Tecoma stans (L.) against human breast cancer cells in vitro Res. J Pharm Biol Chem Sci, 4, 305-13.

Vahedi F, Najafi MF, Bozari K (2008). Evaluation of inhibitory effect and apoptosis induction of Zyzyphus Jujube on tumor cell lines, an in vitro preliminary study. Cytotech, 56, 105-111.

Veeresh SK (2010). Anthelmintic activity of Zizyphus jujuba Mill \& Lamk. J Pharm Bio Sci, 2, 63-65.

Wu G, Qian Z, Guo J, et al (2012). Ganoderma lucidum extract induces $\mathrm{G} 1$ cell cycle arrest, and apoptosis in human breast cancer cells. Am J Chin Med, 40, 631-642. 